\title{
Integration of LED-based lighting in academic buildings for energy efficiency considerations
}

\author{
Mohamad Zhafran Hussin, Saiful Firdaus Abdul Shukor, Nor Diyana Md Sin, Yusrina Yusof, \\ Muhammad Zairil Muhammad Nor, Noor Hasliza Abdul Rahman \\ Faculty of Electrical Engineering, Universiti Teknologi MARA Cawangan Johor, Kampus Pasir Gudang, Malaysia
}

\begin{tabular}{l} 
Article Info \\
\hline Article history: \\
Received Feb 28, 2020 \\
Revised Apr 9, 2020 \\
Accepted Jun 23, 2020 \\
\hline
\end{tabular}

\section{Keywords:}

Building lighting system Energy Efficiency

Fluorescent lamp (FL)

Light emitting diodes (LEDs)

\begin{abstract}
This paper presents an assessment by integration of LED T8 tube lamps in academic buildings for energy efficiency considerations. The proposed project was implemented in conjunction with a national mission, national energy efficiency action plan (NEEAP) for 10-year implementation period of 2016-2025 in reducing allocation on subsidies for efficient expenditure towards energy-saving measures. A case of study in a real environment at one of the UiTM's buildings as a target task area has been tested by replacing a LED lighting technology in consideration of current operating costs and power factor performances. From the results, LED T8 tubes have shown a better power factor of 0.89 compared to fluorescent lamps with about 0.61 and primarily driven by economic benefits in terms of cost savings of up to $50 \%$ with return-on-investment (ROI) 6 months after installation. By integrating this technology, nearly $50 \%$ of the total energy consumption in indoor lighting system could be significantly saved, thus reducing the total cost of electricity bills in the future within the target area.
\end{abstract}

This is an open access article under the CC BY-SA license.

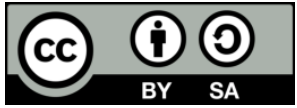

\section{Corresponding Author:}

Mohamad Zhafran Hussin,

Faculty of Electrical Engineering,

Universiti Teknologi MARA Cawangan Johor, Kampus Pasir Gudang,

81750 Masai, Johor Malaysia.

Email:mzhafran@uitm.edu.my

\section{INTRODUCTION}

The light emitting diodes (LEDs) technology opens new perspective in the lighting field due to its higher energy efficiency and lower power consumption. The new cutting edge of LED technology could indeed and become more reasonable in a future as a replacement for conventional fluorescent technology that is widely used in commercial and industrial spaces either interior or exterior of buildings and roadways lighting $[1,2]$. As compared to conventional technology such as fluorescent lamp (FL) and compact fluorescent lamp (CFL), LEDs have several advantages where it can save around 30\% to $50 \%$ of energy consumption, less maintenance costs, easier handling as well as longer life expectancy [3]. As LED tube prices are still expensive as compared to conventional fluorescent technology and the trend of energy consumption is very critical among ASEAN countries, the government of Malaysia provides various support measures for this technology under energy efficiency program (EEP) through National Energy Efficiency Action Plan (2016-2025) and Implementation of EE Projects under 11th Malaysia Plan (2016-2020). A great achievement during 2011-2015, where the retrofitting of four existing government buildings resulted in a reduction of electricity usage from $4 \%$ to $19 \%$ per month, which is equivalent to MYR7,000 to MYR130,000 savings [4]. According to researchers and the energy commission (EC), air-conditioning and lighting systems have proven to be the major consumers by $57 \%$ and $20 \%$ of electricity usage in office buildings in Malaysia $[5,6]$. Nowadays, LEDs are the newest addition to energy efficient light source listings and are used as one of the key components of energy saving strategies [7]. 
Since the technology of LED lighting advance in recent years, it also be represented as a green technology-based, the issue of power quality is becoming more important to overlook [8-10]. The study was conducted by Velan et al. [3] shown that the major problem related to power quality such as total harmonic distortion (THD), active power and power consumption can be reduced if using LED technology. A similar finding was discovered by Mauro et al. [11] under laboratory measurement, which determines the electrical quantities and characteristics of CFLs and LED lamps are dissimilar for different manufacturers. According to the authors, the obtained current drawn by LEDs are less distorted than CFL lamps, and certain LEDs manufacturer gives a good indicator in terms of power factor. In terms of active power, CFLs load varies almost linearly with supply voltage when the input voltage is varied, and in contrast to the LEDs are appeared to be less dependent on voltage. The study was carried out by Usman et al. [12], where it has analyzed the technical aspects of LEDs and CFLs in terms of harmonic, active power consumption, power factor, and apparent power. The majority of the findings indicates that LEDs have high current in THD and lower in power factor $[13,14]$. During the observation, although the apparent power of LED and CFL lamps are higher, the stability of LEDs is faster responses than CFLs after being switched on. It has shown that LEDs have given more advantages over CFLs. Under controlled conditions, Lin et al. [15], performed a comparative study of power quality characteristics on incandescent, CFL and LED lamps with similar luminous fluxes. From the result obtained, as active power increases, power factor is decreased. With the same luminous flux, the annual cost of electricity indicates that LED is more economical than CFL. This study also supported by recent researcher where the number of lighting are chosen to be reduced through delamping method and successfully reduced the electricity consumption, especially in maintenance and electricity bill [16-18].

Several researchers have evaluated the performances of power quality and other issues such as life cycle assessment and recycling waste of LED technology either indoor or outdoor building lighting applications also found similar findings, where it can be reduced power consumption up to $40 \%-50 \%$, lower THD rates, an increase of power factor and efficiency as well as lower environmental impact [1, 19-23]. It has undertaken by Adoghe et al. [24], in domestic lighting applications found that the power factor of LED lighting system with a lagging power factor has improved up to 0.85 as compared to conventional fluorescent lamps. In most cases, power factor is less important to the residential owner. However, commercial or industrial owners may be charged an additional fee by utility provider if their power factor is too low [25]. Under Malaysia's environment, a penalty charges or power factor surcharge is imposed when a power factor is less than 0.90 (electricity supply $132 \mathrm{kV}$ and above) or less than 0.85 (electricity supply below $132 \mathrm{kV}$ ). The surcharge of power factor will be charged around $1.5 \%$ for every 0.01 less than 0.85 and $3 \%$ for every 0.01 less than 0.75 for customers with electricity supply below $132 \mathrm{kV}$ [26]. Therefore, this study will present a comparative study by investigating fluorescent and LED tube T8 lamps in one of UiTM's buildings with current operating costs as well as energy quality of power factor performances on the building lighting systems, in conjunction with a national mission towards energy saving measures. On the other hand, this study also hopes to create awareness on energy consumption patterns in public universities, especially in the use of lighting systems, which can be as a reference point for future activities [27-30].

\section{RESEARCH METHOD}

\subsection{Lighting system features}

The testing is divided into two types of configuration components; fluorescent and LED tube. The testing duration and data recording such as voltage, current and power factor; are conducted within a short period of time under 24 hours of operation. The performance testing tested using both fluorescent and LED tubes with similar fixtures, based on similar manufacturer brand for benchmark testing. By utilizing LED lighting technology as an alternative option, the strategies are to reduce energy consumption and saving maintenance costs such as the replacement of tubes and ballasts, over long-term duration. This retrofitting can be easily implemented using the existing T8 lighting fitting and casing. Table 1 presents a summary from similar manufacturer data on both lighting specification of fluorescent and T8 LED T8 tube lamps. All specifications related to the selected lighting system meet the quality of lighting comfort based on the requirements of Malaysian Standard (MS 1525:2014) under the recommended average illuminance levels for lighting for working interiors [31].

Table 1. Specification T8 lighting of fluorescent and LED tubes [32, 33]

\begin{tabular}{lll}
\hline \multicolumn{1}{c}{ Description } & \multicolumn{1}{c}{ Fluorescent lamp } & \multicolumn{1}{c}{ LED tube } \\
\hline Model & FL TL-D LIFEMAX Super 80 & Ecofit T8 \\
Tube Wattage & $36 \mathrm{~W}$ & $16 \mathrm{~W}$ \\
Lifetime & $20,000 \mathrm{hrs}$ & $15,000 \mathrm{hrs}$ \\
Luminous Flux & $3070 \mathrm{~lm}$ & $1600 \mathrm{~lm}$ \\
Light Colour/Colour code & $6500 \mathrm{k} / 865$ & $6500 \mathrm{k} / 765$ \\
\hline
\end{tabular}

Bulletin of Electr Eng \& Inf, Vol. 10, No. 1, February 2021 : 93 - 100 


\subsection{Laboratory testing setup}

Under testing set-up, the technical differences between theoretical and actual measurements for both T8 lighting lamps in terms of energy consumption and power factor has been investigated. Figure 1 shows the process of testing set-up for the fluorescent and LED tube T8 lamps. Both lighting systems have chosen from similar manufacturers with the specified power rating is 36 Watt for fluorescent lamp and 16 Watt for LED Ecofit tube respectively. All the relevant parameters such as voltage, current and power factor were measured and recorded by a single-phase energy and power quality meter via Fluke 43B, as illustrated in Figure 2.

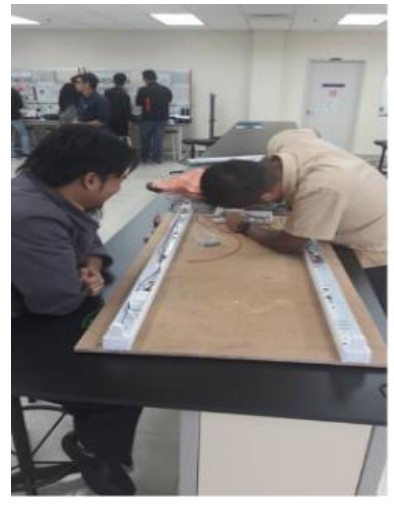

(a)

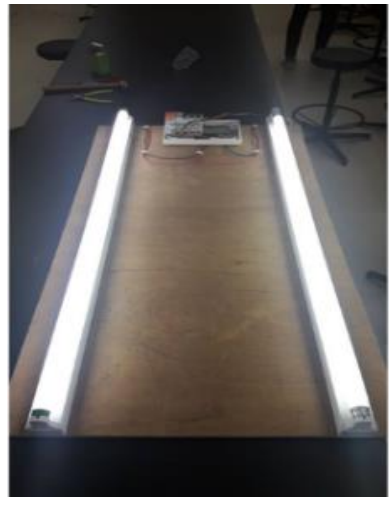

(b)

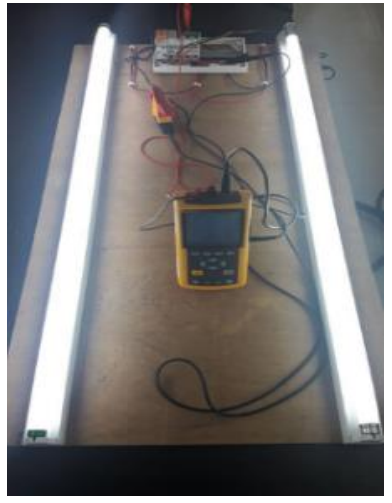

(c)

Figure 1. The testing set-up for lighting system Fluke 43B, (a) Installation of a test board, (b) Fluorescent and LED lamps, (c) Installation of a single-phase energy and power quality meter

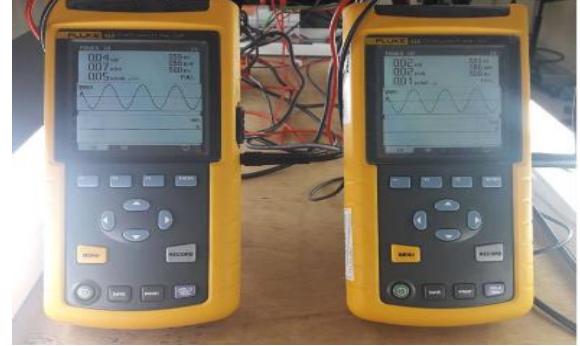

(a)

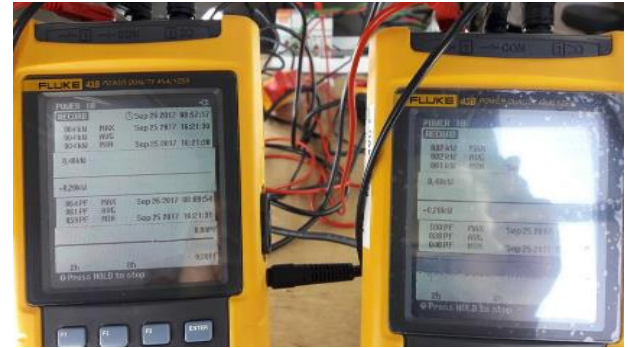

(b)

Figure 2. Recording behaviour monitored by Fluke 43B, (a) Instantaneous sampling, (b) Continuous data

\subsection{Theoretical case study}

A data survey on the amount of lighting appliances reviewed during walk-through audit, thus the energy survey and analysis are made. On the first floor, fluorescent lamp consists of 78 and 23 units for first floor with total usage of fluorescent lamp about 101 units in the entire building. The estimated electricity costs are calculated according to the price rates based on Tariff $\mathrm{C} 1$ (medium voltage general commercial tariff). From Table 2, it is shown that the entire building uses annual energy consumption of 9,031.82 $\mathrm{kWh}$ /year with total expenditure cost around MYR 3,296.62 for one-year operation. The building comprises of first and second floors where the layout of selected building specifications as shown in Figure 3. In a case study, the techno-economic of replacing fluorescent with LED tube lamps was also discussed.

Table 2. Number of fluorescent T8 lamps with estimated annual energy consumption and electricity cost that comes from building lighting system

\begin{tabular}{lccccc}
\hline $\begin{array}{c}\text { Building Area } \\
\text { per Floor }\end{array}$ & $\begin{array}{c}\text { No. of FL } \\
\text { 36W } \\
\text { (unit) }\end{array}$ & $\begin{array}{c}\text { Estimated daily energy } \\
\text { consumption } \\
\text { (kWh/day) }\end{array}$ & $\begin{array}{c}\text { Estimated daily } \\
\text { electricity bill } \\
\text { (RM/day) }\end{array}$ & $\begin{array}{c}\text { Estimated annual energy } \\
\text { consumption } \\
\text { (kWh/year) }\end{array}$ & $\begin{array}{c}\text { Estimated annual } \\
\text { electricity bill } \\
\text { (RM/year) }\end{array}$ \\
\hline Ground/First & 78 & 25.27 & 9.22 & $6,975.07$ & $2,545.90$ \\
Second & 23 & 7.45 & 2.72 & $2,056.75$ & 750.71 \\
Total Building & 101 & 32.72 & 11.94 & $9,031.82$ & $3,296.62$ \\
\hline *By assuming nine (9) hours operating hours a day and 23 working days a month, tariff rate C1 \\
\hline
\end{tabular}




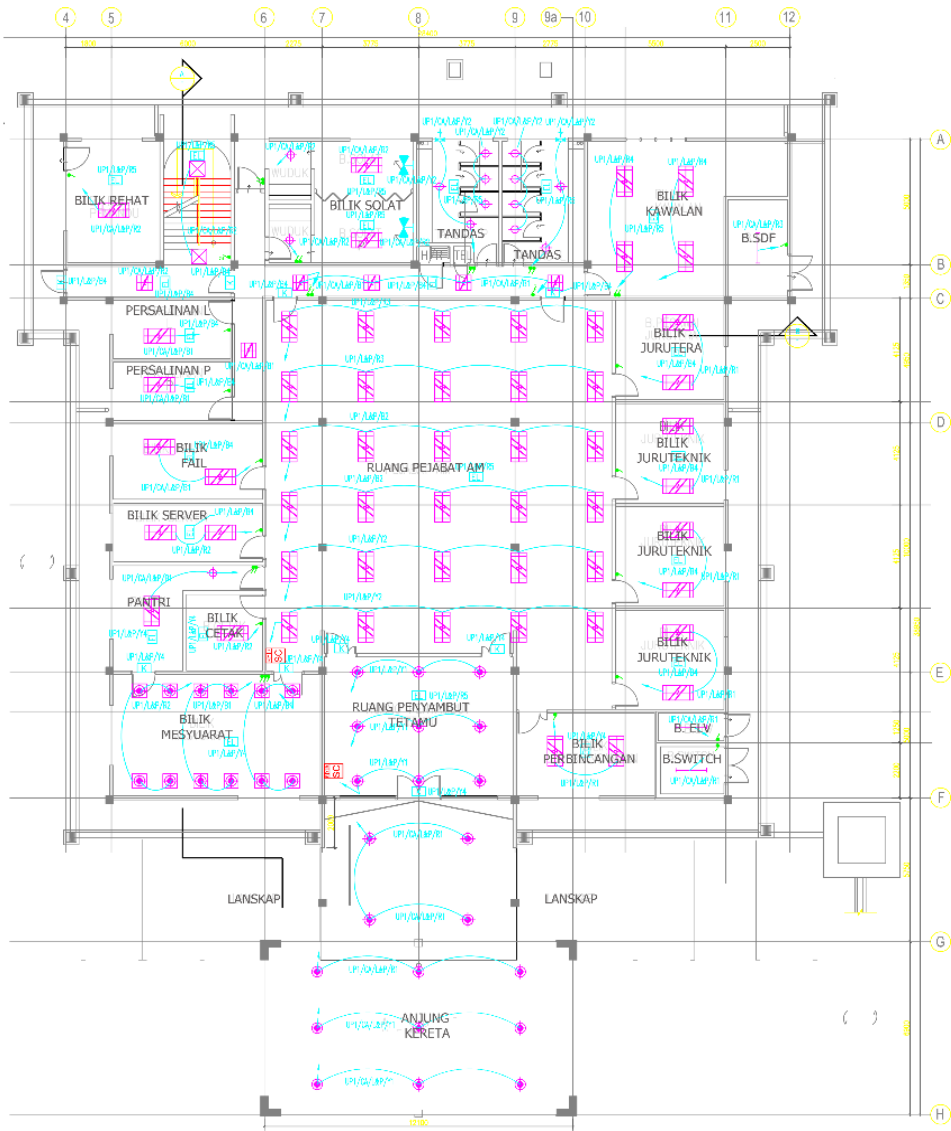

(a)

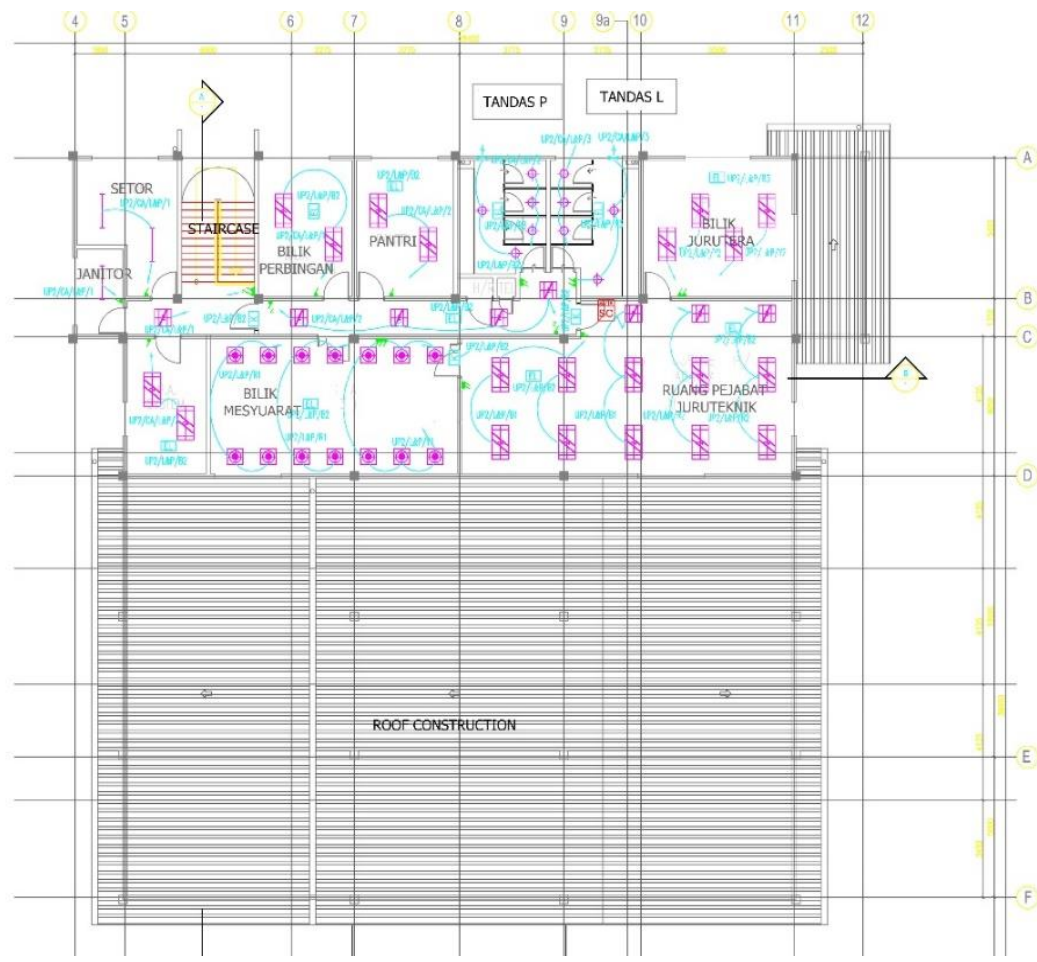

(b)

Figure 3. The layout plan of selected buildings specification, (a) First floor plan, (b) Second floor plan 


\section{RESULTS AND DISCUSSION}

\subsection{Measurement and verification}

The overall trend exhibits good agreement with specifications from manufacturers where the average power consumption of a fluorescent lamp is around $40 \mathrm{~W}$ and $20 \mathrm{~W}$ for LED tube respectively, as can be seen in Figure 4. As expected, LED tube has higher performance in terms of power factor when the recorded data shown that the average power factor is 0.89 better than fluorescent lamp by about 0.61 . While, the measured power factor of fluorescent and LED tube lies in the range between 0.64 to 0.59 and 1.0 to 0.40 , respectively during testing set up. Clearly, the usage of LED tube can increase a power factor as well as to avoid a penalty charge from utility providers. One of the energy saving strategies, all existing fluorescent lamps should be replaced by LED tube lamps that it will help to improve a power factor.
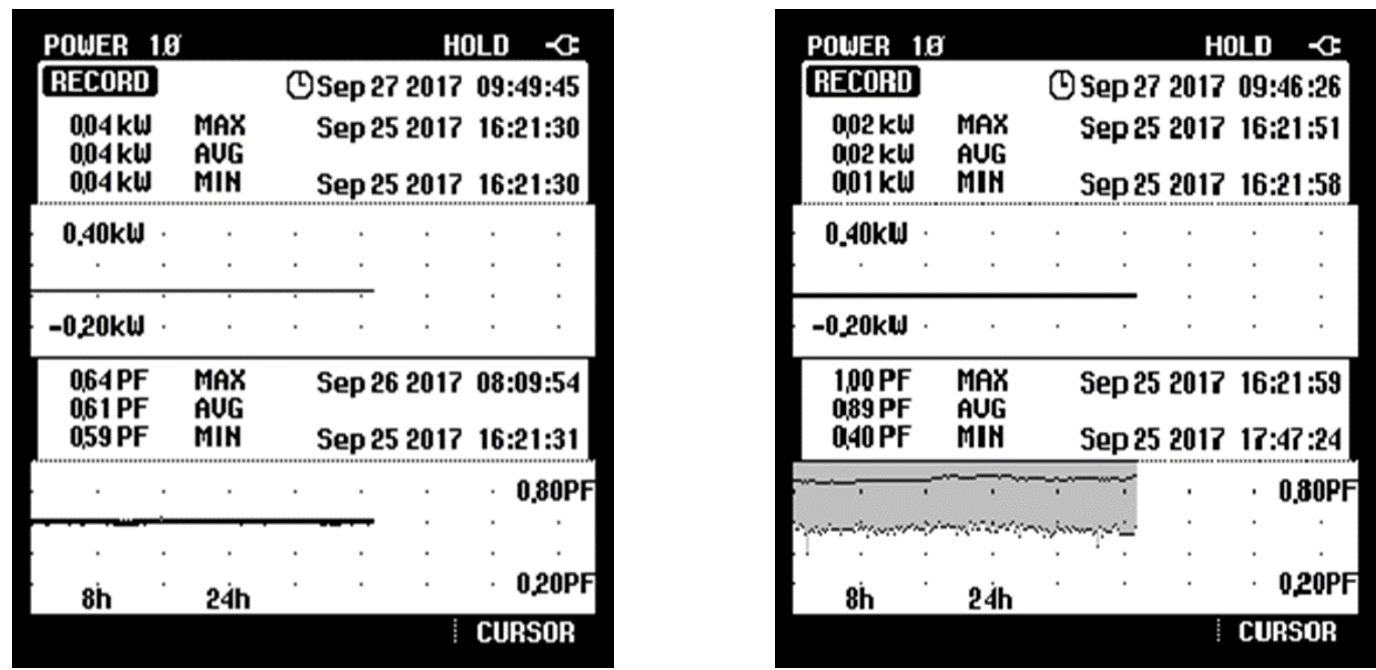

Figure 4. The actual measurement of fluorescent and LED T8 tubes under testing set-up.

\subsection{Comparative analysis between fluorescent and LED tube T8 lamps}

The implication of energy reduction in building lighting system is estimated in terms of cost savings and return-on-investments in between fluorescent with LED tube lamps. By replacing all the existing fluorescent lamps in entire buildings with LED lamps, the estimated cost as shown in Table 3.

Table 3. Estimated cost saving and return-on-investment based on lighting system in building

\begin{tabular}{|c|c|c|}
\hline Criteria & T8 fluorescent & T8 LED \\
\hline Average power consumption (W) & 40 & 20 \\
\hline Working hours per day (h) & 9 & 9 \\
\hline Annual energy consumption ( $\mathrm{kWh} /$ year) & $10,035.36$ & $5,017.68$ \\
\hline Tariff cost (MYR per kWh) & 0.365 & 0.365 \\
\hline \multicolumn{3}{|l|}{ Cost operation } \\
\hline Day & 13.27 & 6.64 \\
\hline One-month & 305.24 & 152.62 \\
\hline Six-month & 1831.45 & 915.73 \\
\hline One-year & 3662.91 & 1831.45 \\
\hline \multicolumn{3}{|l|}{ Cost saving } \\
\hline Day & \multicolumn{2}{|c|}{6.64} \\
\hline One-month & \multicolumn{2}{|c|}{152.62} \\
\hline Six-month & \multicolumn{2}{|c|}{915.73} \\
\hline One-year & \multicolumn{2}{|c|}{1831.45} \\
\hline Total investment (MYR) & \multicolumn{2}{|c|}{909.00} \\
\hline Return-on-investment (Month) & \multicolumn{2}{|c|}{6} \\
\hline
\end{tabular}

As been calculated in Table 3, it shows that the percentage leads to a significant reduction of about $50 \%$ for LED tube compared with fluorescent lamps. Clearly, the usage of fluorescent lamp gives higher energy consumption by about 10,035.36 kWh/year as compared to LED tube around 5,017.68 $\mathrm{kWh} /$ year, thus

Integration of LED-based lighting in academic buildings for energy... (Mohamad Zhafran Hussin) 
making a significant decrease in operating cost if the building is replaced with LED lighting technology. In terms of electricity bills, almost half reduction can be clearly seen in the case of operating costs where it can save, annual expenses up to 1831.45 MYR as illustrated in Figure 5. In addition, a study based on return-oninvestment (ROI) concerning LED lighting technology used in building is also calculated where it provided an initial return of 6 months of period after installation.

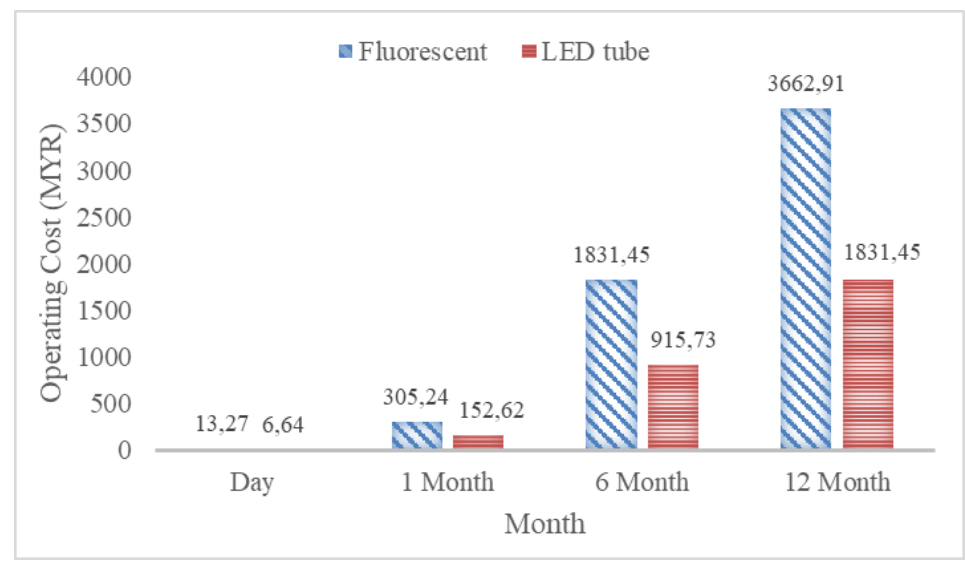

Figure 5. The comparison of estimated operating cost between fluorescent and LED T8 tubes over months

\section{CONCLUSION}

A promising result as an alternative way for energy saving to replace all existing conventional fluorescent with LED lighting technology. From these findings, it could be estimated the electricity bills up to $50 \%$ of total reduction as well as enhanced a power factor for the entire building consumption. Although initial cost is expensive, it can be recommended as an option to secure on the long-term operating expenses (OPEX) in terms of maintenance and labors. In addition, the findings are expected to be beneficial to management in the decision-making process as well as to provide a significant improvement towards energy efficient technology.

\section{ACKNOWLEDGEMENTS}

The authors acknowledge the support of the Management of Universiti Teknologi MARA (UiTM) and financially funded by the Malaysia Ministry of Education [600-RMI/FRGS 5/3 (083/2019] grant. Also, thanks to the Energy Management Committee in UiTM Cawangan Johor, Kampus Pasir Gudang for their professional support and commitment to this research.

\section{REFERENCES}

[1] A. K. Nair, Arunraj, N. Kumar, J. C. Ramya, and V. Kirubakaran, "Performance analysis of LED and florescent lamps a case study of street lightning system," 2016 International Conference on Energy Efficient Technologies for Sustainability (ICEETS), pp. 850-855, 2016.

[2] D. Jenkins, R. Gibbert, and A. Jayawardena, "Led performance and application considerations for industrial environments," 2017 Annual Pulp, Paper And Forest Industries Technical Conference (PPFIC), pp. 1-7, 2017.

[3] S. S. S. Velan, M. Venkateshwaran, C. A. Vigneshwari, M. A. Mydeen, and V. Kirubakaran, "Performance and economic analysis of room lighting system-A case study," $20163 \mathrm{rd}$ International Conference on Electrical Energy Systems (ICEES), pp. 244-250, 2016.

[4] Unit Perancang Ekonomi Malaysia, "Eleventh Malaysia plan, 2016-2020: Anchoring growth on people," Economic Planning Unit, Prime Minister's Department, 2015.

[5] Suruhanjaya Tenaga, "Guidelines on no-cost and low-cost measures for efficient use of electricity in buildings," Suruhanjaya Tenaga (Energy Commision), 2014.

[6] R. Saidur, "Energy consumption, energy savings, and emission analysis in Malaysian office buildings," Energy Policy, vol. 37, no. 10, pp. 4104-4113, 2009.

[7] J. S. Hassana, R. M. Zinb, M. Z. Abd Majidc, S. Balubaida, and M. R. Hainin, "Building energy consumption in Malaysia: An overview," Jurnal Teknologi, vol. 70, no. 7, pp. 33-38, 2014.

[8] J. I. Silva, V. Sousa, P. Sarmiento, J. R. Gómez, P. R. Viego, and E. C. Quispe, "Effects of power electronics devices on the energy quality of an administrative building," International Journal of Power Electronics and Drive System, vol. 10, no. 4, pp. 1951-1960, 2019. 
[9] J. Perko, S. Nikolovski, and L. Majdandžić, "Comparative analysis of power quality indices for different lighting techniogies in public lightning," International Journal of Electrical and Computer Engineering, vol. 8, no. 2, pp. 880-887, 2018.

[10] A. Gil-de-Castro, A. Moreno-Munoz, A. Larsson, J. J. G de la Rosa, and M. H. J Bollen, "LED street lighting: A power quality comparison among street light technologies," Lighting Research \& Technology, vol. 45, no. 6, pp. 1-19, 2012.

[11] S. Di Mauro and A. Raciti, "Analysis and comparison of CFLs and LED lamps," 2014 AEIT Annual Conference From Research to Industry: The Need for a More Effective Technology Transfer (AEIT), pp. 1-6, 2014.

[12] M. Usman, F. Shahnia, G. M. Shafiullah, and A. Arefi, "Technical comparison of the domestic LEDs and CFLs available on the Australian market," 2017 North American Power Symposium (NAPS), pp. 1-6, 2017.

[13] C-A. Cheng, E-C. Chang, C-H. Tseng, and T-Y. Chung, "A single-stage LED tube lamp driver with power-factor corrections and soft switching for energy-saving indoor lighting applications," Applied Sciences, vol. 7, no. 2, pp. 115-128, 2017.

[14] R. Ayaz, K. Dogansahin, A. Bozkurt, and B. Kekezoglu, "Power quality assessment of indoor LED luminaires," 2019 Electric Power Quality and Supply Reliability Conference (PQ) \& 2019 Symposium on Electrical Engineering and Mechatronics (SEEM), pp. 1-7, 2019.

[15] S. Lin, N. Huang, and M. Zhu, "The study of the power quality emission characteristics of different types of lamps and their impacts on distribution systems," 2016 IEEE 11th Conference on Industrial Electronics and Applications (ICIEA), pp. 613-618, 2016.

[16] M. F. M. Ab Halim, M. F. Yaakub, M. H. Harun, K. A. M. Annuar, F. Hj Md Basar, and M. N. Omar, "An analysis of energy saving through delamping method," International Journal of Electrical and Computer Engineering, vol. 9, no. 3, pp. 1569-1575, 2019.

[17] Y. Jiang, S. Li, B. Guan, G. Zhao, D. Boruff, L. Garg, and P. Patel, "Field evaluation of selected light sources for roadway lighting," J. of Traffic and Transportation Engineering (English Edition), vol. 5, no. 5, pp. 372-385, 2018.

[18] H. Khorasanizadeh, J. Parkkinen, R. Parthiban, and J. D. Moore, "Energy and economic benefits of LED adoption in Malaysia," Renewable and Sustainable Energy Reviews, vol. 49, pp. 629-637, 2015.

[19] B. Z. Yuksek and U. Dakeev, "Management of urban parking lot energy efficiency with the application of wind turbine and LED lights," Bulletin of Electrical Engineering and Informatics, vol. 3, no. 1, pp. 9-14, 2014.

[20] R. Gunabalan, "Overview of passive light emitting diode driver circuits for street lighting," Bulletin of Electrical Engineering and Informatics, vol. 5, no. 3, pp. 307-314, 2016.

[21] P. Principi and R. Fioretti, "A comparative life cycle assessment of luminaires for general lighting for the office compact fluorescent (CFL) vs light emitting diode (LED) - a case study," Journal of Cleaner Production, vol. 83, pp. 96-107, 2014.

[22] N. Phannil, C. Jettanasen, and A. Ngaopitakkul, "Harmonics and reduction of energy consumption in lighting systems by using LED lamps," Energies, vol. 11, no. 3, pp. 3169-3195, 2018.

[23] K. Bertin, L. Canale, O. B. Abdellah, Marc-André M., and G. Zissis, "Life cycle assessment of lighting systems and light loss factor: A case study for indoor workplaces in France,” Electronics, vol. 8, no.11, pp. 1278-1296, 2019.

[24] Adoghe A. U., Odigwe I. A., Orovwode H. E., Agbetuyi A.F., Awosope C. O. A., and Ogazi C. S., "Development of a light emitting diode lighting system with power factor correction for domestic applications," International Journal of Energy Technology Research, pp. 1-6, 2014.

[25] R. Saidur, N. A. Rahim, H. H. Masjuki, S. Mekhilef, H. W. Ping, and M. F. Jamaluddin, "End-use energy analysis in the Malaysian industrial sector," Energy, vol. 34, no. 2, pp. 153-158, 2009.

[26] Tenaga Nasional Berhad, "Electricity supply application handbook," Kuala Lumpur, Malaysia: Distribution Division TNB, pp. 7-130, 2011.

[27] H. D. Muhammad, "The energy audit process for universities accommodation in Malaysia: a preliminary study," IOP Conference Series: Earth and Environmental Science, vol. 67, no. 1, p. 012027, 2017.

[28] E. Leiva, S. Villacreses, and D. S. Benítez, "Electrical energy audit of university buildings: Case study at Universidad San Francisco de Quito," 2018 IEEE ANDESCON, pp. 1-6, 2018.

[29] H. Singh, M. Seera, and M. A. Mohamad Idin, "Electrical energy audit in a Malaysian university - a case study," 2012 IEEE International Conference on Power and Energy (PECon), pp. 616-619, 2012.

[30] C. K. Gan, A. F. Sapar, Y. C. Mun, and K. E. Chong, "Techno-economic analysis of LED lighting: A case study in UTeM's faculty building," Procedia Engineering, vol. 53, pp. 208-216, 2013.

[31] Firrdhaus Sahabuddin, "MS1525:2014 Energy efficiency and use of renewable energy for non-residential buildings -Code of practice," SIRIM Berhad, Malaysia, 2014.

[32] Philips Lighting, "L-D LIFEMAX Super 80 Technical data specification," Philips Lighting, Ed., [Revised Feb. 2018] ed, 2018.

[33] Philips Lighting, "Philips Ecofit LEDtube T8 Technical data specification," Philips Lighting, Ed., [Revised Jul. 2015] ed, 2015. 


\section{BIOGRAPHIES OF AUTHORS}
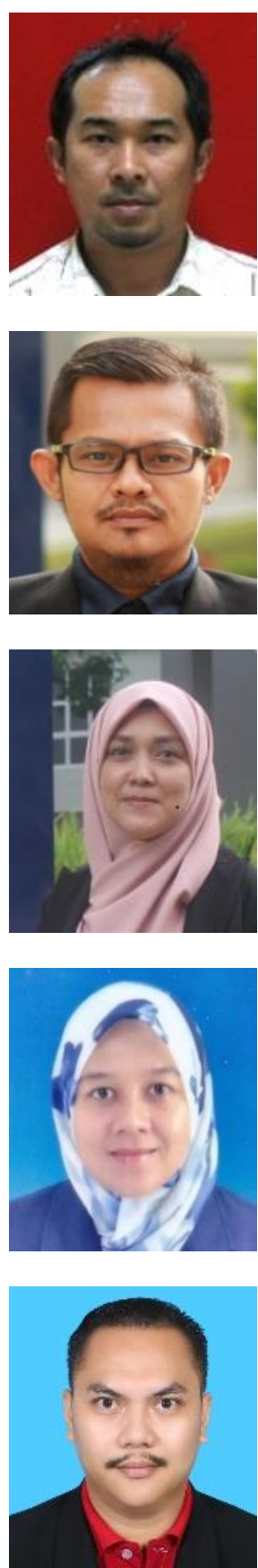

Muhammad Zairil Muhammad Nor received the bachelor's degree in Electrical Engineering (Telecommunication) from Universiti Teknologi Malaysia (UTM), Skudai, in 2009, and the M.Sc. by Research degree in Electrical Engineering also from Universiti Teknologi Malaysia (UTM), Skudai, in 2013. He is currently a lecturer in Faculty of Electrical Engineering, UiTM Cawangan Johor, Kampus P. Gudang. He has published more than 15 journal papers and technical proceedings on smart antenna systems, microwave devices, and reconfigurable antenna in national and international journals and conferences. His research interest includes smart antenna on communication systems.

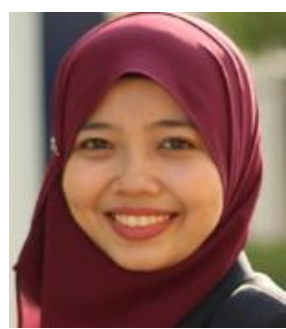

Noor Hasliza Abdul Rahman received her B. Eng. (Hons) in electrical engineering from Universiti Putra Malaysia (UPM) in 2006 and M.Sc in Electrical Engineering from at Universiti Teknologi MARA in 2014. Since 2014, she has been a lecturer in Department of Power, Faculty of Electrical Engineering, Universiti Teknologi MARA, Cawangan Johor Kampus Pasir Gudang. Her field of interest is Photovoltaics and Renewable Energy (RE) technologies. 